\title{
PAULINA BARAN
}

Poznań

\section{Niemiecki model polityki społecznej na tle regulacji Unii Europejskiej}

\section{Wprowadzenie}

Państwa Unii Europejskiej są bardzo zróżnicowane pod względem kierunków i sposobu prowadzenia polityki społecznej. Pomimo, iż Unia dąży w pewnym zakresie do integracji także na polu spraw socjalnych, to jednak kreowanie szczegółowych rozwiązań w tym obszarze nadal pozostaje domeną państw członkowskich. Niemniej jednak, nie jest to równoznaczne $\mathrm{z}$ brakiem przepisów regulujących tę sferę na poziomie unijnym. Wręcz przeciwnie, aktualnie z uwagi na przyszłe problemy wynikające m.in. z poważnych przeobrażeń zachodzących w demograficznej strukturze UE, obserwuje się wzmożone zainteresowanie kwestiami społecznymi, traktowanymi w kategoriach wyzwań.

\section{Modele polityki społecznej państw Unii Europejskiej}

Rozpatrując podejścia do polityki społecznej, mając na uwadze występujące różnice, można w oparciu o cechy wspólne dokonać ich podziału na grupy modelowe. W literaturze przedmiotu spotyka się wiele typologii odnoszących się do różnych kryteriów demarkacyjnych. Warto w tym miejscu także zauważyć, iż w obszarze zainteresowań twórców poszczególnych typologii leżą przede wszystkim rozwiązania stosowane w państwach Europy Zachodniej oraz kilku pozaeuropejskich potęgach takich jak USA, Australia, Kanada czy Nowa Zelandia. Zasadniczo w sowich analizach ich autorzy pomijają kraje rozwijające się i do niedawna także byłe kraje socjalistyczne ${ }^{1}$.

Biorąc pod uwagę stosowane w Europie rozwiązania w zakresie polityki społecznej, często ujmuje się je w kategoriach Europejskiego Modelu Społecznego (EMS, ang. European Social Model). Zasadniczo pojęcie to odnosi się do ,rozbudowanego zestawu celów, instrumentów i polityk zabezpieczenia społecznego, rozwiniętych i powszechnie stosowanych w państwach europejskich w okresie po II wojnie światowej, i opartych na wartościach, takich jak: solidarność, sprawiedliwość społeczna, poszanowanie godności i zapewnienie możliwości swobodnego rozwoju jednostki"². W drugiej

\footnotetext{
1 Polityka społeczna. Podręcznik akademicki, red. G. Firlit-Fesnak, M. Szylko-Skoczny, Warszawa 2008, s. 145.

2 D. K. Rosati, Europejski Model Społeczny. Osiagnięcia, problemy i kierunki zmian, w: Europejski Model Społeczny. Doświadczenia i przyszłość, red. D. K. Rosati, Warszawa 2009, s. 23.
} 
połowie XX w. w krajach Europy Zachodniej zarówno funkcje, jak i cele socjalne realizowane w ramach ogólnej polityki państwa uległy znacznemu rozbudowaniu, co doprowadziło do ukształtowania się zasadniczo nowej fory państwa, zwanej państwem opiekuńczym lub państwem dobrobytu. Pomimo zbieżności, należy uznać, iż nie istnieje jeden uniwersalny Europejski Model Społeczny. Jego krajowe odmiany różnią się zarówno zakresem i rodzajem zabezpieczenia społecznego, jak również instrumentami służącymi wdrażaniu szczegółowych rozwiązań w zakresie polityki społecznej. Odnosząc się do EMS, należy także zaznaczyć, iż w istocie zbliżone założenia do tych leżących u jego podłoża, stosowane są także w wielu pozaeuropejskich państwach wysoko rozwiniętych, tj. Kanada, Japonia, Australia czy Nowa Zelandia ${ }^{3}$.

Richard Titmuss biorąc pod uwagę relacje, jakie zachodzą między polityką społeczną a gospodarką rynkowa, wyodrębnił trzy jej modele:

- marginalny zwany też rezydualnym (ang. the residualwerfare model) - u jego podstaw leży założenie o dwóch podstawowych i zarazem właściwych kanałach zaspokajania potrzeb indywidualnych, tj. rynku prywatnym oraz rodzinie; polityka społeczna jest w nim rozumiana jako doraźny mechanizm interwencyjny uruchamiany w sytuacjach, gdy one zawodzą;

- motywacyjny, inaczej służebny bądź wydajnościowy (ang. the industrialachievment-performance model, handmaiden model) - programy socjalne pełnią w nim funkcję służebną wobec gospodarki, stanowiąc jednak ważny jej dodatek; w procesie zaspokajania potrzeb wysoką rangę przypisuje się do kwestii zasług i wydajności pracy;

- instytucjonalno-redystrybucyjny (ang. the institutional-redistributive model) - polityka społeczna jest pojmowana jako integralna instytucja danego społeczeństwa pełniąca funkcję redystrybucji dochodów, a dostęp do jej usług i świadczeń opiera się na zasadach powszechności, w szczególności z uwzględnieniem kryterium potrzeb ${ }^{4}$.

Państwa w prowadzonej polityce socjalnej różnią się także stopniem ingerencji w życie obywateli, a tym samym poziomem przyjmowanej odpowiedzialności ${ }^{5}$. Można wyodrębnić kilka stanowisk w tym zakresie, poczynając od polityki prowadzonej w oparciu o zasady państwa minimalnego, a na państwie opiekuńczym kończąc. Uwzględniając zróżnicowany system świadczeń i polityk socjalnych, Katarzyna Głąbicka wyodrębnia cztery podstawowe modele występujące w państwach członkowskich UE, do których zalicza:

Ibidem, s. 23.

4 G. Firlit-Fesnak, M. Szylko-Skoczny (red.), Polityka społeczna..., op. cit., s. 145.

5 Do kryterium poziomu ingerencji państwowej w wolną grę rynkową odnieśli się także Norman Furniss i Dorothy Tilton, który wyróżnili: państwo pozytywne (ang. the positivestate, the social service state), państwo bezpieczeństwa socjalnego (ang. the socialsecuritystate) oraz państwo dobrobytu społecznego (ang. the socialwelfarestate). Wedle zasad pierwszego z nich, zadaniem polityki społecznej jest ochrona właścicieli kapitału przed potencjalnymi trudnościami związanymi z grą rynkową oraz żądaniami redystrybucji dochodów, czemu służyć ma rozbudowany system ubezpieczeń społecznych wyrównujących dochody oraz przenoszących odpowiedzialność związaną z bezrobociem lub chorobą z jednostki na całe społeczeństwo. Celem państwa bezpieczeństwa socjalnego jest zagwarantowanie wszystkim obywatelom minimalnego dochodu. Natomiast dążenia państwa dobrobytu społecznego zmierzają w kierunku wyrównania warunków życia. 
- korporacyjny (konserwatywny) charakteryzujący się tym, iż państwo zapewnia podstawowe bezpieczeństwo socjalne, jednakże wiele w tym zakresie funkcji sprawują organizacje pozarządowe, religijne i zrzeszenia obywateli; występuje w Niemczech, Holandii, Belgii, Austrii i Finlandii;

- rezydualny (liberalny) opierający się na idei wolnego rynku, wolności jednostki, równości; obywatele samodzielnie winni zaspokajać własne potrzeby społeczne i socjalne zaś pomoc ze strony państwa traktowana jest jako ostateczność; jest stosowany w Wielkiej Brytanii;

- rudymentarny (elementarny) występujący w państwach słabych ekonomicznie, w których pomoc społeczna w głównej mierze oparta jest na dobroczynności i działalności organizacji pozarządowych, państwo zapewnia jedynie podstawową ochronę socjalną; jest realizowany w Portugalii, Hiszpanii, Grecji i Irlandii;

- opiekuńczy (socjalny) jest najbardziej rozwinięty, podstawą jest zapewnienie zatrudnienia i wysokiej jakości usług socjalnych, jest charakterystyczny dla krajów skandynawskich - Szwecji, Danii, Holandii ${ }^{6}$.

Odnosząc się do polityki społecznej, ujmowanej w kategoriach modelowych, należy mieć na uwadze, iż są to konstrukty teoretyczne służące uporządkowaniu wiedzy, niewątpliwie przydatne także $\mathrm{w}$ prowadzeniu międzypaństwowych analiz porównawczych. Niemniej jednak szczegółowe rozwiązania stosowane nawet w państwach zasadniczo zaliczanych do danego modelu, mogą się znacznie różnić.

\section{Unijne rozwiązania w obszarze polityki społecznej}

Polityka społeczna w początkowym okresie integracji europejskiej nie stanowiła obszaru priorytetowego Europejskiej Wspólnoty Gospodarczej, choć jej podstaw należy upatrywać już w Traktatach Rzymskich ${ }^{7}$. Trzeba jednak zauważyć, iż zawarte w Traktacie ustanawiającym Europejską Wspólnotę Gospodarczą przepisy dotyczące sfery socjalnej stanowiły jedynie postulaty i nie miały mocy prawnej. Pierwsze zapisy dotyczace poprawy warunków życia i pracy znalazły się już w preambule traktatu. Podkreślono także wagę ścisłej współpracy państw członkowskich w obszarze spraw socjalnych, a w szczególności w kwestiach dotyczących zatrudnienia, praw, warunków i higieny pracy, szkoleń i doskonalenia zawodowego, zabezpieczenia społecznego, ochrony przed wypadkami i chorobami zawodowymi, praw do zrzeszania się w związki zawodowe oraz sporów na linii pracodawca-pracownik. Znalazł się w nim także zapis dotyczący równości wynagrodzeń dla kobiet i mężczyzn za tę samą pracę ${ }^{8}$. Na mocy art. 123 powołano Europejski Fundusz Społeczny, którzy swoją praktyczną działalność rozpoczął w $1960 \mathrm{r}$. Jego pierwotnym celem była poprawa możliwości zatrudnienia pracowników w ramach rynku wewnętrznego oraz stworzenie warunków sprzyjających zwiększeniu ich mobilności wewnątrzwspólnotowej"

6 K. Głąbicka, Polityka socjalna w Unii Europejskiej, „Studia Europejskie” 1997, nr 4, s. 54.

725 marca 1957 r. zostały podpisane: Traktat ustanawiający Europejską Wspólnotę Gospodarczą (EWG) oraz Traktat ustanawiający Europejską Wspólnotę Energii Atomowej (Euratom). Oba znane są pod wspólną nazwą Traktatów Rzymskich.

8 Traktat ustanawiający Europejską Wspólnotę Gospodarczą, art. 117-119.

9 Ibidem, art. 123-125. 
Wynikające ze sprzyjającej koniunktury gospodarczej oraz dobrej sytuacji na rynku pracy niewielkie zainteresowanie sprawami polityki społecznej na poziomie wspólnotowym w pierwszej fazie integracji europejskiej było ściśle związane także z faktem, iż poziom rozwoju gospodarczego w państwach członkowskich był wówczas zbliżony, a same systemy socjalne były zasadniczo podobne. W związku z tym początkowe przepisy EWG w sferze socjalnej ograniczały się do wprowadzenia ułatwień w zakresie swobodnego przepływu pracownikó $w^{10}$ oraz ich dostosowania do potrzeb rynkowych. Bezpośrednio tych kwestii dotyczyło rozporządzenie Rady z dnia 15 października 1968 r. ${ }^{11}$, którym uregulowano m.in. sprawę dostępności do zatrudnienia na obszarze EWG obywateli państw członkowskich, równego ich traktowania oraz zagadnienia związane $\mathrm{z}$ rodzinami pracowników. Kwestie zabezpieczenia społecznego ${ }^{12}$ migrujących pracowników i ich rodzin uregulowane zaś zostały w rozporządzeniu $\mathrm{z}$ dnia 14 czerwca $1971 \mathrm{r}^{13}$ Zainteresowanie sprawami socjalnymi wyraźnie wzrosło dopiero w latach 70. ubiegłego stulecia, kiedy w 1972 r. na szczycie szefów państw i rządów w Paryżu kwestie socjalne uznano za równie ważne jak rozwój gospodarczy. W odpowiedzi na sformułowane wówczas zalecenia opracowano pierwszy Program Działań Społecznych (ang. Social Action Programme) ${ }^{14}$, który wyznaczał trzy główne cele:

- osiagnięcie we Wspólnocie zatrudnienia pełnego i na lepszych warunkach;

- poprawa warunków życia i pracy;

- wzrost wpływu partnerów społecznych na polityczne i gospodarcze decyzje EWG w kwestiach ekonomicznych oraz zwiększenie roli pracowników w procesie podejmowania decyzji w zatrudniających ich przedsiębiorstwach ${ }^{15}$.

10 Kwestia swobody przepływu pracowników w obrębie Wspólnoty została poruszona już w art. 48 i 49 Traktatu ustanawiającego EWG.

11 Rozporządzenie Rady (EWG) nr 1612/68 z dnia 15 października 1968 r. w sprawie swobodnego przepływu pracowników wewnątrz Wspólnoty (Dz. U. WE L 257 z 19.10.1968).

12 Problemu zabezpieczenia społecznego w kontekście realizacji swobody przepływu pracowników dotyczy także art. 51 Traktatu ustanawiającego EWG.

13 Rozporządzenie Rady (EWG) nr 1408/71 z dnia 14 czerwca 1971 r. w sprawie stosowania systemów zabezpieczenia społecznego do pracowników najemnych i ich rodzin przemieszczających się we Wspólnocie (Dz. U. L 149 z 5.07.1971).

14 Został on przyjęty w dniu 21 stycznia 1974 r. przez Radę Ministrów na mocy rezolucji Rady z dnia 21 stycznia 1974 r. o programie działań spotecznych (Dz. U. C 13 z 12.02.1974). Programy Działań Społecznych są uruchamiane przed Komisję Europejską okresowo, a ich głównym celem jest wspieranie unijnych celów w zakresie kwestii społecznych poprzez wykrywanie obszarów dla wspólnotowych inicjatyw, które mogą przybrać postać legislacyjnych propozycji lub też, co się zdarza znacznie częściej, niejurydycznych działań.

${ }^{15}$ W celu realizacji założeń Programu, Rada w następnych latach przyjęła kilka dyrektyw stanowiących fundament polityki zatrudnienia, dotyczących równych szans dla kobiet i mężczyzn oraz bezpieczeństwa i higieny pracy, a także programy działań na rzecz osób niepełnosprawnych, ubogich i starszych. Wśród najistotniejszych warto wymienić: dyrektywę Rady nr 75/117/EWG z dnia 10 lutego 1975 r. w sprawie zblizenia ustawodawstw Państw Członkowskich dotyczqcych stosowania zasady równości wynagrodzeń dla mężczyzn i kobiet (Dz. U. L 45); dyrektywę Rady nr 76/207/EWG z dnia 9 lutego 1976 r. $w$ sprawie wprowadzenia w życie zasady równego traktowania kobiet i mężczyzn w zakresie dostępu do zatrudnienia, ksztatcenia i awansu zawodowego oraz warunków pracy (Dz. U. L 39); dyrektywę Rady nr 79/7/EWG z dnia 19 grudnia 1978 r. w sprawie stopniowego wprowadzania w życie równego traktowania kobiet i mężczyzn w dziedzinie zabezpieczenia społecznego (Dz. U. L 6); dyrektywę Rady nr 75/129/EWG z dnia 17 lutego 1975 r. w sprawie ujednolicenia przepisów praw- 
W latach 80. XX w. kwestie społeczne ponownie zeszły na dalszy plan, czego powodów upatruje się w procedurze podejmowania decyzji w Radzie, która wymagała jednomyślności. Źródłem takiego stanu rzeczy były także bez wątpienia odmienne wizje państw członkowskich, co do roli Wspólnoty w kreowaniu polityki społecznej. Zmiany w tym obszarze przyniosło dopiero wprowadzenie Jednolitego Aktu Europejskiego ${ }^{16}$, którego zasadniczym celem było ustanowienie dostosowań w zakresie funkcjonowania rynku wewnętrznego. Jego regulacje odnoszące się do polityki społecznej koncentrują się na zagadnieniach bezpieczeństwa i higieny pracy. Jako cel wyznaczono harmonizację warunków pracy, ochrony zdrowia i bezpieczeństwa pracowników, czemu służyć miała procedura przyjmowania minimalnych wymagań większością kwalifikowaną w drodze dyrektyw, stopniowo następnie wprowadzanych w życie ${ }^{17}$. Podkreślono w nim także wagę wzmocnienia spójności gospodarczej i społecznej ${ }^{18}$.

Ważnym krokiem w obszarze wyznaczania europejskich standardów w dziedzinie praw pracowniczych było przyjęcie w 1989 r. przez 11 państw członkowskich (z wyłączeniem Wielkiej Brytanii) ${ }^{19}$ Wspólnotowej Karty Podstawowych Praw Socjalnych Pracowników (ang. The Community Charter of the fundamental social rights of workers $)^{20}$. Pomimo, iż Karta nie jest prawnie wiażącym aktem wspólnotowym, to jednak stanowi bardzo ważny dokument, w którym określono prawa socjalne, jakie winny być zagwarantowane na europejskim rynku pracy. Obejmuje ona 12 głównych obszarów. W celu implementacji postanowień Karty, Komisja przygotowała kolejny Program Działań Społecznych, który zawierał 47 samodzielnych inicjatyw ${ }^{21}$. W jego ramach uchwalono m.in. dyrektywę Rady w sprawie obowiązku pracodawcy dotyczącego informowania pracowników o warunkach stosowanych do umowy lub stosunku pracy ${ }^{22}$ oraz dyrektywy dotyczące bezpieczeństwa i zdrowia pracowników w miejscu pracy.

Kompetencje Wspólnoty w sferze polityki socjalnej zostały poszerzone na mocy postanowień Traktatu o Unii Europejskiej ${ }^{23}$. Wspieranie wysokiego poziomu zatrud-

nych państw czlonkowskich dotyczacych zwolnień grupowych (Dz. U. L 48); dyrektywę Rady $\mathrm{nr}$ 77/187/EWG z dnia 14 lutego 1977 r. w sprawie ujednolicenia przepisów prawnych państw członkowskich dotyczacych ochrony praw pracowników podczas przejęcia przedsiębiorstwa, zakładu lub części zaktadu (Dz. U. L 61); dyrektywę Rady nr 80/987/EWG z dnia 20 października 1980 r. o ochronie pracowników w przypadku niewypłacalności pracodawcy (Dz. U. L 283).

16 Jednolity Akt Europejski został podpisany 17 lutego 1986 r. w Luksemburgu oraz 28 lutego 1986 r. w Hadze. W życie wszedł 1 lipca 1987 r.

17 Jednolity Akt Europejski, art. 118a.

18 Jednolity Akt Europejski, art. 130a-d.

19 Wielka Brytania nie wyraziła zgody na włączenie Karty do Traktatu Rzymskiego z obawy, iż może ona stać się podstawą do wprowadzania rozwiązań prawnych mających negatywny wpływ na elastyczność rynku pracy, a co za tym idzie także i konkurencyjność gospodarki.

${ }^{20}$ Znana jest także pod nazwą Wspólnotowej Karty Socjalnej i z tego też powodu często mylona jest z odrębnym dokumentem Rady Europy, tj. Europejską Kartą Socjalną z 1961 r. Niemniej należy w tym miejscu zaznaczyć, iż ta druga wraz z konwencjami Międzynarodowej Organizacji Pracy, stanowiła dla niej podstawę.

${ }^{21} \mathrm{http}: / /$ www.eurofound.europa, z dnia 12.07.2011.

22 Dyrektywa Rady nr 91/533/EWG z 14 października 1991 r. $w$ sprawie obowiazku pracodawcy dotyczqcego informowania pracowników o warunkach stosowanych do umowy lub stosunku pracy (Dz. U. WE L 288).

${ }_{23}$ Traktat o Unii Europejskiej został podpisany 7 lutego 1992 r. w Maastricht, wszedł w życie 1 listopada 1993 r. Traktat z Maastricht zmienił nazwę Europejskiej Wspólnoty Gospodarczej na Wspólnotę Europejską. 
nienia oraz ochrony socjalnej zostały oficjalnie włączone do kategorii zadań UE. Panująca w latach 90. XX w. dwoistość rozwiązań dotyczących polityki społecznej Wspólnoty, wynikająca ze zgłaszanych przez Wielką Brytanię zastrzeżeńn ${ }^{24}$, została ostatecznie rozwiązana wraz z podpisaniem Traktatu amsterdamskiego ${ }^{25}$. Po uzgodnieniu pewnych zmian we wcześniejszym Porozumieniu w sprawie polityki społecznej ${ }^{26}$, jego treść została włączona do Traktatu (art. 136-145) uzyskując akceptację wszystkich państw członkowskich, łącznie z Wielką Brytanią. Dotychczas stosowana procedura współpracy została zastappiona procedurą współdecyzji (art. 137). Rozszerzono również zakres działalności Wspólnoty na rzecz równości kobiet i mężczyzn. Ponadto wymagające dotychczas jednomyślności obszary także objęto procedurą współdecydowania w zakresie przepisów dotyczących:

- Europejskiego Funduszu Społecznego;

- ułatwienia wykonania prawa obywateli do swobodnego przemieszczania się i przebywania na terytorium państw członkowskich;

- zabezpieczenia społecznego pracowników migrujących w obszarze Wspólnoty.

Rada, na mocy nowego artykułu 13, uzyskała również kompetencje w sprawie podejmowania wszelkich środków na rzecz walki z dyskryminacja, pod warunkiem uzyskania w tej kwestii jednomyślności po konsultacjach z Parlamentem. Regulacje te leżały u podłoża dwóch, niedługo potem uchwalonych dyrektyw dotyczących równego traktowania ${ }^{27}$.

Od połowy lat 90. XX w. polityka społeczna Unii Europejskiej wyraźnie ukierunkowana jest na wielosektorowość. Promowane wówczas pluralistyczne podejście w kwestii rozwiązywania problemów społecznych znalazło odzwierciedlenie w licznych programach, dokumentach i strategiach, takich jak Biała Księga „Wzrost, konkurencyjność, zatrudnienie zmiany i drogi zbliżenia do XXI wieku" z $1993 \mathrm{r}^{28}$ czy też Zielo$n^{29}$ i Biała Księga Polityki Społecznej (1994 r.) ${ }^{30}$. Odnotowany w kilku państwach

24 Wielka Brytania zakwestionowała proponowane zmiany, jakie zawierało Porozumienie w sprawie polityki społecznej i ostatecznie go nie podpisała. Zjednoczone Królestwo na mocy klauzuli opt-out wyłączone zostało także z postanowień protokołu nr 14 do Traktatu ustanawiającego Wspólnotę Europejską.

${ }_{25}$ Traktat z Amsterdamu został ostatecznie podpisany (łącznie z protokołami i deklaracjami) 2 października 1997 r. Pełna, formalna jego nazwa to: Traktat zmieniający Traktat o Unii Europejskiej, traktaty ustanawiające Wspólnoty Europejskie oraz niektóre związane z nimi akty.

26 Porozumienie zostało zawarte między Europejskimi Partnerami Społecznymi (ang. European Social Partners), organizacjami pracodawców (UNICE i CEEP), związkami zawodowymi oraz Europejską Konferencją Związków Zawodowych (ang. European Trade Union Confederation - ETUC) i zostało dołączone do Protokołu nr 14 do Traktatu ustanawiającego Wspólnotę Europejska.

27 Dyrektywa Rady 2000/43/WE z dnia 29 czerwca 2000 r. wprowadzajaca w życie zasadę równego traktowania osób bez względu na pochodzenie rasowe lub etniczne (Dz. U. WE L 180 z 19.07.2000); dyrektywa Rady 2000/78/WE z dnia 27 listopada 2000 r. ustanawiajaca ogólne warunki ramowe równego traktowania w zakresie zatrudnienia i pracy (Dz. U. WE L 303 z 2.12.2000).

28 Growth, Competitiveness, Employment: The Challenges and Ways Forward into the 21 st Century - White Paper. Parts A and B. COM (93) 700 final/A and B, 5 December 1993. Bulletin of the European Communities, Supplement 6/93.

29 European Social Policy - Options for the Union - Green Paper, COM (93) 551 final, 17 November 1993.

${ }^{30}$ European Social Policy -A Way Forward for the Union - White Paper COM (94) 333 final, 27 July 1994. Szeroko nt. kierunków przeobrażeń polityki społecznej patrz: M. Grewiński, Wielosektorowa polityka społeczna. O przeobrażeniach państwa opiekuńczego, Warszawa 2009. 
członkowskich na początku lat 90. ubiegłego stulecia wysoki wzrost poziomu bezrobocia przyczynił się dodatkowo do uznania polityki wspierania wzrostu zatrudnienia za jeden z priorytetów Wspólnoty. W konkluzji posiedzenia Rady Europejskiej w Essen, które odbyło się w 1994 r., wyrażono przekonanie o konieczności podejmowania wspólnego wysiłku na rzecz szukania najlepszych rozwiązań, czemu przysłużyć się miało zobowiązanie do lepszej koordynacji polityk poszczególnych krajów. W tym celu uruchomiono Europejską Strategię Zatrudnienia, której ugruntowanie legislacyjne zostało wprowadzone Traktatem amsterdamskim.

Postanowienia Traktatu z Nicei ${ }^{31}$ nie wprowadziły zasadniczych zmian w obszarze polityki społecznej. Na jego mocy utworzono Komitet ds. Ochrony Socjalnej, którego podstawowym zadaniem jest wspieranie współpracy między państwami członkowskimi a Komisją w zakresie ochrony socjalnej. Niemniej jednak wnioski dotyczące rozszerzenia procedury współdecydowania, zostały odrzucone. Wprowadzone traktatem zmiany nie były rozległe. Do ważnych dokonań szczytu w Nicei należy zaliczyć proklamację przez przywódców państw UE, Komisję Europejską oraz Parlament Europejskiej Karty podstawowych praw Unii Europejskiej ${ }^{32}$. W jego trakcie podjęto także kroki w kierunku stworzenia unijnej strategii zwalczenia ubóstwa i wykluczenia społecznego.

Poważne zmiany w zakresie polityki społecznej zostały ustalone podczas Rady Europejskiej, która odbyła się w marcu 2000 r. w Lizbonie ${ }^{33}$. W strategii będącej efektem szczytu, dostrzeżono potrzebę modernizacji europejskiego modelu społecznego przede wszystkim poprzez inwestowanie w kapitał ludzki oraz zwalczanie wykluczenia społecznego. Głównym celem w obszarze polityki zatrudnienia, jaki wyznaczono do 2010 r., był wzrost średniego wskaźnika zatrudnienia do poziomu ok. 70 z ówczesnej płaszczyzny $61 \%$ oraz zwiększenie udziału kobiet w rynku pracy z 51 do ponad $60 \%{ }^{34}$. Uczestniczący w Radzie szefowie państw i rządów zadeklarowali poprawę współpracy w kwestiach eliminacji ubóstwa i wykluczenia społecznego. Uzgodnili także, iż polityka zwalczania tych zjawisk winna opierać się na otwartej metodzie koordynacji, której głównym założeniem jest połączenie krajowych planów działania oraz programu

31 Pełna nazwa Traktatu nicejskiego brzmi: Traktat z Nicei zmieniający Traktat o Unii Europejskiej, Traktat ustanawiający Wspólnotę Europejską i niektóre związane z nimi akty (Dz. U. C 80, z 10.03.2001).

32 Karta podstawowych praw Unii Europejskiej (Dz. U. UE 303). Bezpośrednio kwestii socjalnych dotyczą art. $34 \mathrm{w}$ zakresie zabezpieczenia społecznego i pomocy społecznej, czy też art. 35 w doniesieniu do ochrony zdrowia. Znalazły się w niej jednak również zapisy odnoszące się do zakazu niewolnictwa i pracy przymusowej (art. 5), prawa do podejmowania pracy (art. 15), a także inne prawa dotyczące kwestii pracy i zatrudnienia.

33 Poczynione w trakcie Rady ustalenia znalazły odzwierciedlenie w dokumencie The Lisbon Strategy - Making Change Happten (Commision Staff Working Paper, Brussels, 15.01.2002 COM(2002), 14 final), w którym zawarto program społeczno-gospodarczy Unii Europejskiej na lata 2000-2010, znany powszechnie jako Strategia Lizbońska. Głównym jej celem było stworzenie w ciagu zaledwie dekady gospodarki dynamicznej, wysoce konkurencyjnej i podlegającej trwałemu rozwojowi. Do głównych obszarów wymagających podjęcia działań w celu urzeczywistniania jej założeń obok innowacyjności, liberalizacji rynków i przedsiębiorczości zaliczono także spójność społeczną. Patrz szerzej: J. Babiak, Realizacja Strategii Lizbońskiej warunkiem konkurencyjności Unii Europejskiej, w: Wyzwania i zagrożenia dla Europy XXI wieku, red. J. Babiak, Poznań 2008.

34 http://circa.europa.eu, z dnia 12.07.2011. 
współpracy zaproponowanego przez Komisję Europejską. Rada Europejska odniosła się ponadto do kwestii europejskich systemów ochrony socjalnej, które jak zauważono, wymagały modernizacji. Dostrzeżono również problem w obszarze polityki rentowo-emerytalnej, stąd też wezwano państwa członkowskie do głębszej w tej dziedzinie współpracy. Przełożenie założeń Strategii na konkretne działania zostało zawarte w komunikacie Komisji COM (2000) 379, który stał się podstawą przyjęcia na szczycie w Nicei europejskiej agendy polityki społecznej do 2005 r. mającej na celu modernizację europejskiego modelu społecznego. W tym względzie położono nacisk na potrzebę większej koordynacji polityki gospodarczej, społecznej oraz polityki zatrudnienia. Podjęto decyzję, iż poziom jej wdrażania będzie corocznie kontrolowany i poddawany analizie przez Komisję Europejską na wiosennym szczycie ${ }^{35}$.

W 2005 r. dokonano śródokresowego przeglądu osiągnięć we wdrażaniu Strategii Lizbońskiej $^{36}$, które uznano za niewystarczające. Rada Europejska stwierdziła także, iż na poziomie poszczególnych państw członkowskich, obserwuje się wysoką niejednolitość w obszarze realizowania wyznaczonych nią celów. Podkreślono ponadto konieczność zwiększenia wysiłków w kierunku urzeczywistnienia jej założeń w szczególności w kontekście dokonujących się przeobrażeń sfery gospodarczej i społecznej będących wynikiem globalizacji, wzrostu konkurencyjności a nade wszystko związanych ze wzrostem bezrobocia, migracją zarobkową oraz problemem starzejącego się społeczeństwa $^{37}$. Ustalenia te znalazły odzwierciedlenie w tzw. Odnowionej Strategii Lizbońskiej, w której cele wcześniejszych ustaleń zostały ograniczone do dwóch, tj. osiagnięcie zrównoważonego wzrostu gospodarczego oraz trwałego wzrostu zatrudnienia. Diagnoza przyczyn niepowodzeń realizacji założeń z 2000 r. pozwoliła na przeformułowanie wcześniejszych, ogólnych wytycznych w spawie zatrudnienia w Zintegrowane Wytyczne na rzecz wzrostu i zatrudnienia na lata $2005-2008^{38}$. Dokumentem tym nałożono na państwa członkowskie obowiązek opracowania Krajowych Programów Reform (KPR), dzięki którym lizbońskie cele i priorytety uzyskać miały wymiar narodowy.

Mając na uwadze poważne przeobrażenia, jakie obecnie zachodzą na europejskim rynku pracy oraz w kwestiach społecznych, na poziomie wspólnotowym podejmuje się

35 Ibidem.

36 Już pięć lat od przyjęcia Strategii Lizbońskiej postępy w jej wdrażaniu oceniono jako niedostateczne. Do głównych przyczyn tego stanu rzeczy zaliczono m.in. zbyt wolne tempo reform w krajach członkowskich oraz niski poziom koordynacji między nimi. Uznano, iż wpływ na to ma również zbyt duża liczba wyznaczonych pierwotnie priorytetów. W konsekwencji zobowiązano państwa członkowskie do przygotowania trzyletnich programów reform. Ponadto wyznaczono pięć obszarów wymagających wzmożonych działań, do których zaliczono: wiedzę i technologię, rynek wewnętrzny, przedsiębiorstwa i otoczenie, środowisko naturalne, a także rynek pracy.

37 Zachodzącym obecnie i zasadniczo nieuniknionym zmianom demograficznym został poświęcony Komunikat Komisji Zielona Księga „Wobec zmian demograficznych: nowa solidarność między pokoleniami”, Bruksela, dnia 16.03.2005, COM(2005) 94 końcowy.

38 Wzrost i zatrudnienie - zintegrowane wytyczne na lata 2005-2008 wraz z zaleceniem Komisji w sprawie Ogólnych wytycznych dla polityk gospodarczych Państw Członkowskich oraz Wspólnoty (zgodnie z art. 99 Traktatu WE) oraz Wnioskiem dotyczącym decyzji Rady w sprawie wytycznych dla polityk zatrudnienia Państw Członkowskich (zgodnie z art. 128 Traktatu WE), Bruksela, dnia 12.4.2005 COM(2005) 141 końcowy (Dz. U. nr L 205 z 6.08.2005). 
także działania o charakterze programowym. Celem zwiększenia spójności finansowania w ramach UE w tej dziedzinie, ustanowiono m.in. program PROGRESS. Obok finansowego wspierania wspólnotowych celów w obszarze zatrudnienia oraz spójności społecznej, obejmuje swym zasięgiem także kwestie równości szans. Jest zintegrowanym programem przewidzianym na lata 2007-2013, który zastąpił obowiązujące do 2006 r. cztery programy dotyczące zwalczania dyskryminacji, promowania równouprawnienia kobiet i mężczyzn, środków na rzecz zatrudnienia oraz walki z wykluczeniem społecznym. Zasadniczo nakierowany jest na finansowanie przedsięwzięć w obszarach zatrudnienia, integracji społecznej i ochrony socjalnej, warunków pracy, walki z dyskryminacją oraz równość kobiet i mężczyzn ${ }^{39}$.

\section{Podstawy niemieckiego państwa opiekuńczego}

Polityka społeczna w Niemczech prowadzona jest wedle założeń modelu motywacyjnego, konserwatywno-korporacyjnego, jak jest to określane wedle innej typologii, czy też kontynentalnego. Niemcy rozpatruje się także jako przykład państwa opiekuńczego, wskazując ich kluczowe znaczenie w tworzeniu podstaw funkcjonowania tego modelu. Jego początków upatruje się w polityce prowadzonej przez kanclerza Ottona von Bismarcka, któremu przypisuje się jeden z aktów założycielskich państwa, nie tyle opiekuńczego, co z pewnością socjalnego. Był on inicjatorem wprowadzenia pierwszych uprawnień socjalnych, które choć pojawiły się już w średniowiecznych Niemczech, to jednak dopiero za jego czasów objęto nimi większość grup zawodowych ${ }^{40}$. Pod koniec XIX w. wprowadził on ustawowo trzy typy ubezpieczeń: zdrowotne, od wypadku przy pracy i inwalidztwa oraz emerytalne ${ }^{41}$.

Dokonując ogólnej charakterystyki niemieckiego państwa opiekuńczego, Katarzyna Zamorska wskazała na następujące podstawy jego funkcjonowania:

- państwo opiekuńcze jest swego rodzaju umową społeczną zawartą między rządem a obywatelami, u podstaw której leży założenie o świadczeniu przez państwo pomocy, którą obywatele nie tylko akceptują, ale też jest ona przez nich oczekiwana, tym samym większość usług i świadczeń ma charakter uprawnieñ ${ }^{42}$;

- istnieje silny związek między uprawnieniami socjalnymi a stosunkiem do pracy - zasadniczo możliwość korzystania z podstawowych świadczeń socjalnych jest ściśle powiązana $\mathrm{z}$ uczestnictwem $\mathrm{w}$ rynku pracy, co jest równoznaczne z koniecznością posiadania statusu pracownika, dla osób jego nieposiadających, pomoc ma charakter fakultatywny;

- koszty pracy są relatywnie wysokie i w dużej mierze wynikają z wysokich świadczeń emerytalno-rentowych;

\footnotetext{
39 http://ec.europa.eu, z dnia 19.07.2011.

40 Średniowieczne ubezpieczenia społeczne obejmowały górników, którzy stworzyli wspólny fundusz ubezpieczający od wypadków przy pracy.

${ }^{41}$ T. Kowalik, Społeczna gospodarka rynkowa - konstytucyjnym wyzwaniem dla Polski, w: M. Kabaj i in., Człowiek - rynek - sprawiedliwość. Szkice, Warszawa 2001, s. 131.

42 Ibidem, s. 139-140.
} 
- mimo, iż znaczna część populacji nie jest zatrudniona, wydajność pracujących jest wyższa niż w innych krajach $^{43}$.

Mając na uwadze różnice w stosowaniu na poziomie państwowym szczegółowych rozwiązań w obszarze polityki społecznej, można zauważyć, iż model państwa opiekuńczego charakterystyczny jest przede wszystkim dla krajów Europy kontynentalnej będących zarazem członkami Unii Europejskiej o najdłuższym stażu ${ }^{44}$. Równie istotne jest, iż są to jednocześnie państwa wywierające duży wpływ na obecny kształt polityki wspólnotowej. Stąd też podkreślana ich rola w wyznaczaniu standardów i kreowaniu zasad unijnej polityki społecznej. W tym względzie w literaturze przedmiotu podkreśla się ważną rolę Niemiec, z doświadczeń których Europa niewątpliwie korzysta w wielu dziedzinach, a w szczególności w obszarze polityki społecznej ${ }^{45}$. Jest to kwestia tym bardziej istotna, iż jak wskazuje Tadeusz Kowalik, model niemiecki jest na tyle stabilny, iż zasadniczo „ostał się przy niewielkich modyfikacjach”46. Co więcej, Niemcy będąc jednym z państw założycielskich, wywierają silny wpływ na kształt polityki wspólnotowej. Przed największym jak dotychczas rozszerzeniem Unii Europejskiej z 2004 r., w Niemczech toczyła się debata szczególnie w kontekście wewnątrzwspólnotowej swobody przepływu pracowników. Wysuwano wówczas obawy, iż po otwarciu granic, tzw. „stara piętnastka” stanie wobec problemu nadmiernego napływu siły roboczej z nowych państw członkowskich. W konsekwencji Komisja Europejska, w szczególności pod naciskami rządów niemieckiego i austriackiego, uchwaliła okresy przejściowe, w trakcie których narodowe rynki pracy podlegały ograniczeniom co do stosowania tejże zasady. Niemniej jednak zauważalny wpływ nie jest kwestią jednostronną. Przynależność do Wspólnoty i kreowane na jej poziomie rozwiązania, wtórnie wpływają na narodową politykę społeczną państw członkowskich. Ponadto przytaczane bywają jako argument na rzecz wprowadzania zmian na poziomie polityki państwowej. Przykładem tego mogą być stanowiące warunek konieczny przystąpienia do unii walutowej i gospodarczej kryteria konwergencji ${ }^{47}$, które w Niemczech służą jako uza-

${ }^{43}$ K. Zamorska, Polityka społeczna Niemiec. Od Bismarckowskich świadczeń socjalnych po Agendę 2010, w: Model spoteczny zintegrowanej Europy. Nowe wyzwania i perspektywy, red. J. Zarzeczny, Wrocław 2007, s. 134-135.

44 Obok Niemiec, jako przedstawicieli prowadzenia polityki społecznej wedle zasady modelu państwa opiekuńczego, zalicza się Austrię, Belgię czy Francję.

45 W. Anioł, Europejska polityka społeczna. Implikacje dla Polski, Warszawa 2003, s. 198.

46 T. Kowalik, Społeczna gospodarka rynkowa..., op. cit., s. 141.

47 Kryteria ekonomiczne, jakie musi spełnić państwo pretendujące do członkostwa w unii walutowej i gospodarczej wyznacza art. 140 ust. 1 Traktatu o funkcjonowaniu Unii Europejskiej. Do wytycznych tych odnosi się także art. 126 tegoż Traktatu oraz Protokół nr 13 w sprawie kryteriów konwergencji (Dz. U. C 115 z 9.5.2008, s. 281) oraz Protokół nr 12 w sprawie procedury dotyczącej nadmiernego deficytu (Dz. U. C 115 z 9.5.2008, s. 279). Stopień konwergencji gospodarczej oceniany jest przez Komisję Europejską i Europejski Bank Centralny na podstawie stopnia spełniania przez dane państwo czterech kryteriów: stabilności cen, fiskalnego, stopy procentowej oraz kursu walutowego. Pierwsze z nich wskazuje, iż przeciętna stopa inflacji z 12 ostatnich miesięcy nie może przekroczyć więcej niż o 1,5 pkt procentowego średniej inflacji z trzech państw o najniższym wzroście cen. Kryterium sytuacji finansów publicznych zakłada, że państwo nie może być objęte procedurą nadmiernego deficytu, co jest równoznaczne z tym, iż deficyt sektora instytucji rządowych i samorządowych nie może przekroczyć poziomu 3\% PKB danego kraju, a jego dług publiczny nie może być wyższy niż $60 \%$ PKB. Kryterium stóp procentowych wskazuje, iż w okresie jednego roku przed bada- 
sadnienie dla redukcji świadczeń socjalnych, gdyż to właśnie w ich wysokości upatruje się źródeł deficytu budżetowego państwa. Prawdą jest, iż Niemcy jako państwo suwerenne decydują o prowadzonej przez siebie polityce społecznej, niemniej jednak należy mieć na uwadze, iż pełne prawo do jej kształtowania podlega ciagłemu procesowi negocjacji między rządami narodowymi a instytucjami ponadnarodowymi. Co więcej, jak się wskazuje, prawo wspólnotowe oraz rozstrzygnięcia Trybunału Europejskiego w ostatnich trzech dekadach wywierają coraz większy wpływ na kształt narodowej polityki społecznej, m.in. poprzez ustanawianie pewnych ogólnych, europejskich standardów $^{48}$. Ponadto nakładają na państwa członkowskie pewne zobowiązania dotyczące np. reform, o czym była mowa we wcześniejszej części opracowania.

\section{Zakończenie}

Polityka społeczna jest obecnie rozpatrywana w kategoriach ważnego czynnika wpływającego zarówno na rozwój poszczególnych państw, jak i samej Wspólnoty. $\mathrm{Z}$ uwagi na aktualne oraz spodziewane przeobrażenia demograficzne, a wraz z nimi zmiany w obszarze rynku pracy i zatrudnienia, niezbędne okazują się reformy szeroko rozumianej polityki sfery spraw społecznych. W perspektywie rozwojowej dla Wspólnoty, ważne jest także stymulowanie współpracy państw członkowskich w tym obszarze. Mimo, iż zasadniczy rdzeń założeń państwa opiekuńczego, w oparciu o który prowadzona jest polityka społeczna Niemiec, nadal jest wyraźny, to jednak pewne zmiany były nieuniknione. Poważne piętno na kształcie prowadzonej dotychczas polityki społecznej, wywarł także niedawny kryzys finansowo-gospodarczy, którego efektem były cięcia w świadczeniach socjalnych. Stąd też nieodzowne jak się wydaje będą dalsze reformy, tak na poziomie Wspólnoty, jak i samych Niemiec. Pomimo, iż polityka społeczna w początkowym okresie integracji europejskiej nie stanowiła głównego obszaru zainteresowań, obecnie rozwiązania przyjmowane na poziomie unijnym, wywierają coraz wyraźniejszy wpływ na kierunek polityki społecznej regulowanej na poziomie narodowym.

niem, średnia, długoterminowa stopa procentowa nie może przekroczyć o więcej niż 2 pkt procentowe średniej stóp procentowych w trzech krajach Unii o najbardziej stabilnych cenach. Ponadto przez co najmniej dwa lata przed wejściem do strefy euro kraj kandydacki musi uczestniczyć w Europejskim Mechanizmie Kursowym (ERM II) i co się z tym wiąże, wahania kursowe jego waluty względem euro muszą być utrzymywane w określonych granicach $(+/-15 \%)$, wokół ustalonej wartości - tzw. parytetu centralnego. W tym czasie waluta nie może także podlegać dewaluacji wobec euro. Warunkiem przystąpienia do Eurolandu jest także spełnianie kryterium konwergencji prawnej, polegającej na zgodności ustawodawstwa krajowego z unijnym. Szerzej na ten temat patrz: http://polskawue.gov.pl, z dnia 30.09.2011.

48 V. Ziegelmayer, Państwo socjalne w Niemczech: zmiana systemu?, w: Państwo socjalne w Europie. Historia-rozwój-perspektywy, red. K. Kraus, T. Geisen, K. Piątek, Toruń 2005, s. 92-94. 


\section{Summary}

\section{The German model of social policy and the European Union regulations}

The essential objective of the paper is to present the German model of social policy as compared to the social solutions adopted in the European Union. The author analyzes the transformations of social policy, established by virtue of the Treaty on the European Union, The Nice Treaty and Lisbon Treaty, among other documents. The further part of the paper presents the main assumptions of the German model of the welfare state. The author concludes with a suggestion that, at a time of global financial crisis, both the European Union and Germany will need to change their social policies. 